\title{
Yeasts isolated from beef heifers with ringworm
}

\author{
Levaduras aisladas de terneras de carne con dermatofitosis
}

\author{
ER Duarte a*, NJF Oliveiraa ${ }^{a}$, AO Medeiros ${ }^{b}$, CA Rosac ${ }^{c}$ EJ Facury-Filho ${ }^{d}$ \\ anstituto de Ciências Agrárias, Universidade Federal de Minas Gerais, \\ Montes Claros, Brasil. \\ bCampus Universitário de Ondina, Universidade Federal da Bahia, \\ Salvador, Brasil. \\ 'Departamento de Microbiologia, Instituto de Ciências Biológicas, \\ Universidade Federal de Minas Gerais, Belo Horizonte, Brasil. \\ dEscola de Medicina Veterinária, Universidade Federal de Minas Gerais, \\ Belo Horizonte, Brasil.
}

\begin{abstract}
RESUMEN
En los bovinos, los dermatofitos producen un impacto negativo en la cría de ganado y pueden causar zoonosis. El objetivo de este trabajo fue describir un brote de tiña en Brasil y evaluar la presencia de levaduras en las lesiones. Después del destete, 88 terneras de carne fueron investigadas clínicamente. Las lesiones típicas de tiña fueron constatadas en $95,5 \%$ de estos animales. En la microscopía directa con hidróxido de potasio se observaron hifas hialinas en 58,8\% de las muestras. Raspados de piel de 27 terneras con tiña fueron inoculados en Agar Dextrosa Sabouraud y Agar Mycosel. Hubo diecinueve aislamientos de Trichophyton spp.. En 24 animales se aislaron levaduras $(88,8 \%)$ y las especies más frecuentes fueron Candida lusitaniae y C. glabrata. El significado de estas levaduras en la etiología y patogenia de la dermatofitosis bovina deben ser evaluadas en nuevos estudios epidemiológicos.
\end{abstract}

Key words: beef cattle, ringworm, filamentous fungi, yeasts, weaning.

Palabras clave: ganado vacuno, tiña, hongos filamentosos, levaduras, destete.

\section{INTRODUCTION}

Mycelial fungi of the species Trichophyton verrucosum, Microsporum canis and Microsporum gypseum are causative agents of dermatophytosis or ringworm in animals and humans worldwide. Their reservoirs are cattle, cats and soil, respectively (Cutsem and Rochette 1991, Hainer 2003, Papini et al 2009). In particular, T. verrucosum is one of the most common chronic zoophilic dermatophytes and bovine dermatophytosis is a zoonosis that may cause significant loss in cattle production (Ming et al 2006, Silver et al 2008). Recently, a cattle farmer has been evaluated with an extensive erythematous plaque that failed to respond to antibacterial treatment. History revealed that his cows were being treated for ringworm and his diagnosis was confirmed by skin biopsy demonstrating fungal elements and culture yielding $T$. verrucosum (Silver et al 2008). Furthermore, a case of mycozoonosis associated with T. verrrucosum, a zoophilic dermatophyte, has been reported due to ringworm of cattle (Ozkanlar et al 2009). Thus, the bovine dermatophytosis, namely

Accepted: 09.08.2012.

* Av. Universitária 1000, Bairro Universitário, Montes Claros, MG 39400-006, Brazil; duartevet@ hotmail.com bovine ringworm, is encountered as an outmost important manifestation for animals and humans in veterinary and medical practice.

The dermatophytes can persist during long periods in the environment and can spread within the herds. Lesions can be found all over the body, but most frequently on the neck, around the eyes, on the forehead and near the ears (Cutsem and Rochette 1991, Gudding and Lund 1995).

In Brazil, few scientific studies have described the occurrence of bovine dermatophytosis (Silveira et al 2003). In addition, there are few investigations on the presence of yeast communities associated with dermatophyte lesions in animals (Cutsem and Rochette 1991, Lacaz et al 2002). The purpose of this study was to describe a ringworm outbreak in heifers raised in Minas Gerais State, Brazil, and to evaluate the yeast species associated with this skin disease.

\section{MATERIAL AND METHODS}

The occurrence of ringworm was evaluated in 88 beef heifers from a farm in the city of Governador Valadares, northeast of Minas Gerais (18 $51^{\prime} 04$ ' $\mathrm{S}$ and $41^{\circ} 56^{\prime} 58$ $\mathrm{W})$. In this region, the climate is very hot with temperatures reaching $35^{\circ} \mathrm{C}$ in summer and $22^{\circ} \mathrm{C}$ in winter, as well as low and irregular rainfall throughout the year (Cetec 1983). 
The animals of this study were 10-month-old females, tree cross 25\% Nelore, 25\% Red Angus and 50\% Canchin.

The presence of smell, itching, increases in volume, ectoparasites, alopecia, excoriations and crust formations were evaluated through clinical examinations of the skin. Circular lesions with asbestos appearance were considered as signals suggestive of clinical bovine ringworm (Cutsem and Rochette 1991, Gründer 1993).

The mycological direct exams were carried out in specimens from all heifers with lesions suggestive of ringworm (84 of 88 animals). The lesions were first rubbed with cotton swab impregnated with $70 \%$ ethyl alcohol for the removal of surface adhering organisms. Skin scales were collected by scraping of the lesion margin using a sterile scalpel blade into sterile petri dish. Hairs were collected by removing dull broken hairs from the lesion margin using sterile tweezers. Potassium hydroxide (KOH 20\%) microscopy was performed to detect fungal structures in skin scrapings or hair (Lacaz et al 2002).

Cultures were evaluated to aliquots specimens from 27 animals with disseminated skin lesions of ringworm (figure 1) and positive $\mathrm{KOH}$ test. The specimens were inoculated on plates containing solid Sabouraud dextrose (Difco Laboratories, Detroit, MI, USA) and Mycosel Agar (Difco Laboratories, Detroit, MI, USA), supplemented with chloramphenicol (final concentration of $150 \mathrm{mg} / \mathrm{l}$ ) and yeast extract (10\% final concentration). The strains were incubated in BOD ovens at $28^{\circ} \mathrm{C}$ and $37^{\circ} \mathrm{C}$ for up to four weeks (Lacaz et al 2002). Clinical specimens of these animals were also cultured in tubes containing the solid medium of Mycosel supplemented with olive oil and incubated at $32^{\circ} \mathrm{C}$ during seven days for Malassezia spp. detection (Guého et al 1998, Duarte et al 2003).

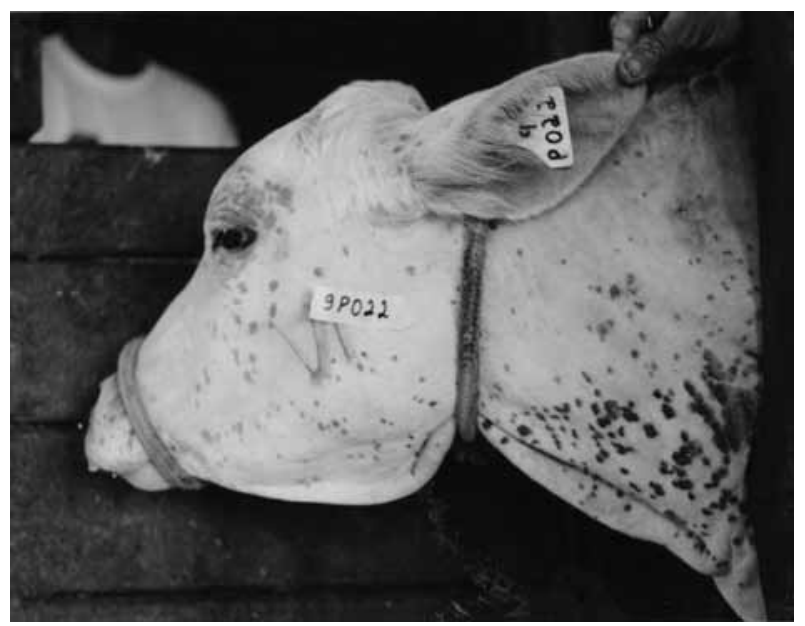

Figure 1. Alopecia and circular crust formation, with asbestos aspects, around the eyes and the neck of a beef heifer with typical disseminated dermatophytosis.

Alopecia y formaciones de costras circulares con aspectos de amianto, alrededor de los ojos y el cuello de una ternera de corte con la típica dermatofitosis diseminada.
Mycelial isolates were identified using microculture technique. Micromorphological characteristics were observed under the light of the optical microscope and compared with fungi structures. Urea hydrolysis was performed culturing Trichophyton isolates on Christensen's solid medium and Dermatophyte Agar. The growth on basal medium with inusitol or thiamine was also considered for identification of these isolates (Rippon 1988, Lacaz et al 2002). Dermatophytes and other fungi were identified according the keys of De Hoog et al (2000). Subsequently to the growth, up to three different yeast colonies were re-isolated to each animal plate and were identified considering the micromorphological and biochemical tests according to the taxonomic keys presented in Kurtzman and Fell (1998). The frequencies of the main species observed were evaluated by Chi Square test at 5\% significance.

The ringworm suggestive animals were isolated from the healthy cattle and moved to pastures with one animal unit per hectare, without confinement stress. These heifers were topically treated with PVP-iodine solution (1\%) daily during a week.

\section{RESULTS AND DISCUSSION}

The occurrence of typical ringworm lesions (figure 1) was observed in 84 animals $(95.5 \%)$. The heifers were weaned and confined at the end of the dry period and the lesions appeared three weeks after the weaning, rapidly spreading among the cattle. Alopecia and circular crust formation started around the eyes, heads and neck, 38 heifers also showed skin lesion throughout the entire body.

The animals with ringworm were separated from the rest of the cattle and were moved to pastures without confinement stress. They were treated with daily topical PVP-iodine application for a week which reduced lesions significantly within two months after treatment.

In this report, high morbidity to lesions suggestive of ringworm was observed in a bovine beef livestock, corresponding to $95.5 \%$ of the evaluated heifers. Direct microscopy with $\mathrm{KOH} 20 \%$ revealed the presence of hyaline thin hiphae in 49 out of 84 exams $(58.3 \%)$ and yeast cellules in 68 out of 84 exams $(80.9 \%)$. The animals were young and were confined in high density just after weaning, from August to September. In this period, the first rains arrived and air humidity increased. These conditions suggest that stress, intense physical contact, higher temperature and humidity favoured the high ringworm occurrence.

During the same period, similar lesions were not observed in 1230 adult cows grazing on extensive pastures, suggesting that confinement, pre-weaning and immaturity were the ringworm promoting factors in this farm. According to Gudding and Lund (1995), these factors should be controlled or considered in order to prevent the rapid spread of the disease.

The transmission and occurrence have been favoured by large scale productions that may cause lack of individual 
animal care. The constant introduction of new animals from other farms in livestock can contribute to the dermatophyte spread. Livestock in restricted areas with high bovine density promotes the dissemination of the disease due to the increased physical contact (Cutsem and Rochette 1991, Gudding and Lund 1995).

Culture test showed presence of Trichophyton spp. in 19 out of 27 sick samples. The most frequent species was Trichophyton verrucosum. Among the saprophytic fungi, the genus Fusarium was the most detected (table 1).

The higher rate of isolates of the genus Trichophyton (70.4\%, $\mathrm{P}<0.01)$ in the 27 sampled animals proves the importance of these fungi in the bovine ringworm etiology (table 1). Among the identified isolates, Trichophyton verrucosum is the main agent in bovine ringworm and is frequently related to temperate regions (Gudding and Lund 1995, Papini et al 2009). T. mentagrophytes and T. soudanense are often associated to human dermatophytosis (Lacaz et al 2002, Chabasse 2008).

Studies evaluated the presence of Trichophyton spp. in bovine healthy skin or with dermatosis in Rio Grande do Sul, State of the Brazil, which has temperate climate and cold weather conditions. Trichophyton verrucosum was isolated in $95.8 \%$ of samples from 142 cattle with clinical suggestive signs of ringworm (Silveira et al 2003). The highest occurrence was also reported in younger animals during autumn and winter (Silveira et al 2003, Ozkanlar et al 2009).

In Japan, the isolation of T. verrucosum in $58.6 \%$ of 29 specimens from skin lesions and $34.8 \%$ of 46 healthy skin areas from calves with ringworm was observed. This species was also isolated in $17.1 \%$ samples from 35 healthy calves. These results suggested that the contact with areas with or without lesions from sick animals could spread the fungus to other animals (Takatori et al 1993).

Other studies have also reported the occurrence of T. mentagrophytes in cattle with dermatophytosis. In the Greece, an reported outbreak was caused only by T. mentagrophytes identified in cultures from $35 \%$ out of a total of 60 evaluated cattle (Kakepis et al 1986). In mycological studies in the India, 150 cattle with typical ringworm lesions revealed the presence of four T. mentagrophytes isolates and 13 Microsporum gypseum (Ranganathan et al 1998). Another research, also carried out in India, evaluated

Table 1. Mycelial fungi and yeasts isolated from 27 beef heifers with disseminated skin lesions of ringworm in the Northeast of Minas Gerais, Brazil.

Hongos filamentosos y levaduras aislados de 27 terneras con lesiones cutáneas diseminadas de tiña en el nordeste de Minas Gerais, Brasil.

\begin{tabular}{|c|c|c|}
\hline Mycological results & Number of animals with positive culture & Occurrence $(\%)$ \\
\hline \multicolumn{3}{|l|}{ Mycelial fungi } \\
\hline Trichophyton spp. & 19 & $70.4 * *$ \\
\hline T. verrucosum & 12 & $44.4 *$ \\
\hline T. mentagrophyte & 5 & 18.5 \\
\hline T. soudanenses & 2 & 7. 4 \\
\hline Fusarium spp. & 5 & 18.5 \\
\hline Acremonium spp. & 1 & 3.7 \\
\hline Aspergillus spp. & 1 & 3.7 \\
\hline Rhizopus spp. & 1 & 3.7 \\
\hline \multicolumn{3}{|l|}{ Yeasts } \\
\hline Candida lusitaniae & 15 & $55.6^{*}$ \\
\hline Candida glabrata & 9 & $33.3 * *$ \\
\hline Candida guilliermondii & 3 & 11.1 \\
\hline Candida albicans & 3 & 11.1 \\
\hline Candida tropicalis & 3 & 11.1 \\
\hline Candida maltosa & 2 & 7.4 \\
\hline Candida parapsilosis & 2 & 7.4 \\
\hline Candida rugosa & 2 & 7.4 \\
\hline Rhodotorula glutinis & 3 & 11.1 \\
\hline Pichia membranifaciens & 3 & 11.1 \\
\hline
\end{tabular}

* Fungi with higher occurrence $(\mathrm{P}<0.01$ in Chi-Square test).

** Fungi with higher occurrence $(\mathrm{P}<0.05$ in Chi-Square test $)$.

* Los hongos con mayor frecuencia $(\mathrm{P}<0,01$ en Chi-cuadrado de prueba).

** Los hongos con mayor frecuencia $(\mathrm{P}<0,05$ en Chi-cuadrado de prueba). 
21 cattle with these lesions and showed the presence of two M. gypseum isolates, and one isolate to the species T. mentagrophytes, T. rubrum and T. similar, respectively (Mitra et al 1998). These studies and the data from this report suggest that other dermatophytes besides $T$. verrucosum may also be involved in the bovine ringworm.

Future studies should also evaluate the presence of the genus Aspergillus, Acremonium, Fusarium and Rhizopus which were identified in this study (table 1), considering that these fungi can be contaminants, saprophytes or opportunists (Rippon 1988, Lacaz et al 2002). Takatori et al (1993) isolated airborne fungi of the genus Aspergillus, Alternaria, Penicillium and Cladosporim from calves with ringworm without implications in the lesions.

Positive cultures to yeasts were observed in 24 heifers $(88.8 \%)$ with disseminated skin lesions of ringworm. The physiological and biochemical identification showed the presence of Candida $(C$.) lusitaniae in 15 animals and $C$. glabrata in 9. Other yeast isolates were identified as $C$. albicans, C. guilliermondii, C. maltosa, C. parapsilosis, C. rugosa, C. tropicalis, Pichia membranifaciens and Rhodotorula glutinosa (table 1). Cultures from ten animals indicated concomitant infections with different yeast species (table 2). The genus Malassezia was not isolated in the evaluated animals.

The culture of clinical specimens of this study shows high ocorrence of yeasts and among isolated yeasts and the most frequent species $(\mathrm{P}<0.05)$ were Candida lusitaniae (58.8\% of positive cultures) and C. glabrata (35.3\% of positive cultures). There are no scientific reports describing the association of these species in dermatophytosis. The high occurrence suggests that further research, examining the role of these and other yeasts in the pathogenesis of bovine ringworm are required. Same yeast of this genus can produce queratinases, lipases and proteases or other enzymes (Duarte et al 2011, Wawron et al 2011), aggravating the ringworm. Further investigation is needed to evaluate the association of this yeast tougher dermatophytes.
Candida lusitaniae has been isolated from several cases of disseminated nosocomial candidiasis in humans. This species frequently shows resistant to amphotericin B and the detection from milk of cows with mastitis also has been reported (Rippon 1988, Kurtzman and Fell 1998, Wawron et al 2011). Species of the Candida and Rhodotorula genera are members of the normal microbiota of warm-blooded animals and have been isolated from external bovine otitis (Duarte et al 2001). The species C. glabrata has also been associated with serious cases of diarrhea in young calves (Elad et al 1998, Elad et al 2002) and C. Rugosa, C. albicans and C. guilliermondii have been isolated from mastitic bovine milk (Santos and Martin 2005).

The high dermatophytosis occurrence observed in these young heifers strengthens their monitoring importance and indicates the need for preventive measures such as reduction of stress during the weaning period and rearing in feedlots. The role of the yeast species identified in this research may also be considered in new studies of the bovine ringworm pathogenesis and their possible transmission forms to humans, animals and the environment.

\section{SUMMARY}

\begin{abstract}
Bovine dermatophytosis has a negative impact in cattle breeding and can cause zoonoses. The aim of this study was to report a ringworm outbreak in Brazil and to evaluate the presence of yeast in the lesions. After weaning, 88 hybrid beef heifers in feedlot were clinically investigated. Lesions suggestive of ringworm were observed in $95.5 \%$ of the animals. Hyaline hiphae were observed in $58.3 \%$ of the samples using direct microscopy with potassium hydroxide. Skin scrapings from 27 heifers with ringworm were inoculated Sabouraud dextrose agar and Mycosel Agar. Nineteen isolates of Trichophyton spp. were identified according to micromorphological characteristics observed with microculture technique. Yeasts were isolated from 24 heifers $(88.8 \%)$ and the most frequently identified species were Candida lusitaniae and C. glabrata. The meaning of these yeast species in the aetiology and pathogeny of bovine dermatophytosis may be evaluated in further epidemiological investigations.
\end{abstract}

Table 2. Beef heifers with disseminated ringworm in the Northeast of Minas Gerais, Brazil and with concomitant yeast infections.

Terneras de corte con lesiones cutáneas diseminadas de tiña en el nordeste de Minas Gerais, Brasil, y con concomitantes infecciones de las levaduras.

\begin{tabular}{cl}
\hline Number of animals with concomitant yeast infections & Mycological identification \\
\hline 1 & Candida glabrata, C. guilliermondii, C. rugosa and C. tropicalis \\
1 & Candida glabrata, . lusitaniae and C. parapsilosis \\
1 & Candida glabrata and $C$. lusitaniae \\
1 & Candida lusitaniae and C. parapsilosis \\
1 & Candida lusitaniae and $C$. albicans \\
1 & Pichia membranifaciens and Candida glabrata \\
1 & Pichia membranifaciens and C. lusitaniae and $C$. albicans \\
1 & Pichia membranifaciens, C. lusitaniae \\
& Pichia membranifacien and Rhodotorula glutinis \\
\hline
\end{tabular}




\section{ACKNOWLEDGEMENTS}

This work was supported by the Fundação de Amparo à Pesquisa do Estado de Minas Gerais (FAPEMIG), Conselho Nacional de Desenvolvimento Científico e Tecnológico (CNPq), and Pró-Reitoria de pesquisa da Universidade Federal de Minas Gerais.

\section{REFERENCES}

Chabasse D. 2008. Dermatophytes: Where do they come from? How did they turn to parasites? Med Mycol 18, 27-35.

Cutsem JV, F Rochette. 1991. Mycoses in domestic animals. Janssen Research Foundation, Beerse, Belgium.

De Hoog GS, J Guarro, MJ Figueras, J Gené. 2000. Atlas of Clinical Fungi. $2^{\text {nd }}$ ed. Centraalbureau voor Schimmelcultures, Utrecht, The Netherlands and Universitat Rovira i Virgili, Reus, Spain.

Duarte ER, JCP Resende, CA Rosa, JS Handam. 2001. Prevalence of yeast and mycelial fungi in bovine parasitic otitis in the state of Minas Gerais, Brazil. J Vet Med 48, 631-635.

Duarte ER, RD Batista, RC Hahn, JS Handam. 2003. Factors associated with the prevalence of Malassezia species in the external ears of cattle from the State of Minas Gerais, Brazil. Med Mycol 41, 137-142.

Duarte TR, SS Oliveira, A Macrae, SML Cedrola, AM Mazotto, EP Souza, ACN Melo, AB Vermelho. 2011. Increased expression of keratinase and other peptidases by Candida parapsilosis mutants. Braz J Med Biol Res 44, 212-216.

Elad D, J Brenner, A Markovics, B Yakobson, S Shlomoviz, J Basan. 1998. Yeasts in the gastrointestinal tract of preweaned calves and possible involvement of Candida glabrata in neonatal calf diarrhea. Mycopathologia 141, 7-14.

Elad D, J Brenner, A Markovitcs, S Shlomoviz, J Basan, N Schwartz. 2002. Influence of diet on the shedding of Candida glabrata by experimentally infected preweaned calves. Vet J 164, 275-279.

Cetec, Centro Tecnológico de Minas Gerais. 1983. Diagnóstico ambiental do Estado de Minas Gerais. Fundação Centro Tecnológico de Minas Gerais, Belo Horizonte, MG, Brasil.

Gründer HD. 1993. Pêlos, pele, tecidos subcutâneo, mucosas aparentes e cornos. In: Dirksen G, Gründer HD, Stöber M (eds). Rosenberger: Exame Clínico dos Bovinos. $3^{\text {th }}$ ed. Guanabara-Koogan, Rio de Janeiro, RJ, Brasil, Pp 81-92.
Gudding R, A Lund. 1995. Immunoprophylaxis of bovine dermatophytosis. Can Vet J 36, 302-306.

Guého E, T Boekhout, HR Ashbee, J Guillot, A Van-Belkum, J Faergemann. 1998. The role of Malassezia species in the ecology of human skin and as pathogens. Med Mycol 36, 220-229.

Hainer BL. 2003. Dermatophyte infections. Am Fam Physician 67, 101-108.

Kakepis E, U Marcelou-Kindi, J Stratigos. 1986. Bovine ringworm. An outbreak caused by Trichophyton mentagrophytes var. granulare in Greece. Int J Dermatol 25, 580-583.

Kurtzman CP, JW Fell. 1998. The yeast: a taxonomic study. $4^{\text {th }}$ ed. Elsevier, Amsterdam, The Netherlands.

Lacaz CS, E Porto, JEC Martins, EM Heins-Vaccari, NT Melo. 2002. Tratado de Micologia Médica Lacaz. $9^{\text {th }}$ ed. Sarvier, São Paulo, SP, Brasil.

Ming PX, YL Xia, GB Bulmer. 2006. Outbreak of Trichophyton verrucosum in China transmitted from cows to humans. Mycopathologia 161, 225-228.

Mitra SK, A Sikdar, P Das. 1998. Dermatophytes isolated from selected ruminants in India. Mycopathologia 142, 13-16.

Ozkanlar Y, MS Aktas, E Kirecci. 2009. Mycozoonosis associated with ringworm of calves in Erzurum Province, Turkey. Kafkas Univ Vet Fak Derg 15, 141-144.

Papini R, S Nardoni, A Fanelli, F Mancianti. 2009. High infection rate of Trichophyton verrucosum in calves from central Italy. Zoonoses Public Hlth 56, 59-64.

Ranganathan S, SAM Balajee, SM Raja. 1998. A survey of dermatophytosis in animals in Madras, India. Mycopathologia 140, 137-140.

Rippon JW. 1988. Medical Mycology, the pathogenic fungi and actinomycetes. $3^{\text {th }}$ ed. Saunders, Philadelphia, USA.

Santos RC, JM Martin. 2005. Isolation of Candida spp. from mastitic bovine milk in Brazil. Mycopathologia 159, 251-253.

Silveira ES, MO Nobre, LL Souza, RO Faria, MB Cleff, MCA Meireles. 2003. Trichophyton verrucosum in bovine with healthy skin and with lesions. Act Scient Vet 31, 45-49.

Silver S, DC Vinh, JM Embil. 2008. The man who got too close to his cows. Diagn Microbiol Infect Dis 60, 419-420.

Takatori K, A Takahashi, S Kawai, S Ichijo. 1993. Isolation of Thichophyton verrucosum from lesional and now-lesional skin in calves. $J$ Vet Med Sci 55, 343-344.

Wawron W, M Bochniarz, M Szczubial. 2011. Enzymatic activity of yeasts isolated from the inflamed mammary secretion in dairy cows. Pol J Vet Sci 14, 65-68. 